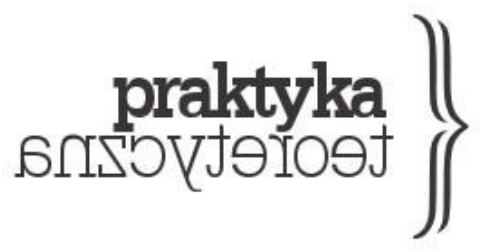

Praktyka Teoretyczna

Numer 2(16)/2015

ISSN 2081-8130

DOI: $10.14746 /$ prt.2015.2.13

www.praktykateoretyczna.pl

\title{
ZAMYKANIE LABORATORIUM
}

\section{PRZEMYSŁAW CZAPLIŃSKI}

\author{
Abstrakt: Artykuł recenzyjny poświęcony książce Arkadiusza Żychlińskiego Laboratorium \\ antropofikcji. Dociekania filologiczne (2014).
}

Słowa kluczowe: krytyka literacka, filologia, posthumanistyka, badania nad mediami 
Laboratorium antropofikcji to jedna z najbardziej oryginalnych, samodzielnych i pożytecznych książek humanistycznych, jakie czytałem w ciagu ostatniej dekady.

Autor już przed publikacją tej książki dał się poznać jako badacz niepospolicie pracowity i mądry. Ma na swoim koncie zbiór szkiców Wielkie nadzieje i dalsze roz̧ważania (2013), współredakcję czterech książek - wartościowych tomów zbiorowych poświęconych Agambenowi, Kafce, Pessoi i Bolano, a ponadto pokaźny dorobek translatorski (samodzielny przekład trzech książek, w tym Gniewu i czasu Petera Sloterdijka oraz Mikrogramów Roberta Walsera, a także ponad pięćdziesięciu artykułów i esejów). Myśląca mrówa - tak można by powiedzieć o autorze, gdyby nie jego zaciekły antropocentryzm (o czym będzie mowa dalej).

W książce Laboratorium antropofikecji postawił przed sobą maksymalistyczne zadanie określenia na nowo roli filologii - i zadanie to (częściowo) wykonał przy użyciu indywidualnie skonstruowanej, oksymoronicznej, empiryczno-spekulatywnej praktyki badawczej.

Metodę, w której znaczącą rolę odgrywają metafory „laboratorium” i „eksperyment” zmajstrował autor z wielu koncepcji. Kierunek, w którym zmierza, dałby się określić jako „humanistyka integralna”, taka więc, która korzysta z narzędzi, hipotez i ustaleń podsuwanych przez wszystkie dyscypliny. Żychliński w swojej mieszance korzysta z osiąnnięć kognitywistyki, biologii, antropologii ewolucyjnej, nauki o języku i neurobiologii. Rezygnując z istniejących metodologii i używając określeń zazwyczaj kojarzonych z naukami ścisłymi, autor wpisuje się w nurt nowej humanistyki, w ramach której stosuje się raczej praktyki badawcze niż metodologie, a kluczową rolę odgrywa słownik pojęciowy, nie zaś stały i powtarzalny zestaw pytań zadawanych dziełu literackiemu. Dąży zaś autor do ustanowienia antropofilologii filologii eksplorującej przestrzeń różnicy antropologicznej (Żychliński 2014, 147), czyli tego, co odróżnia człowieka od nie-ludzi.

U podstaw całej koncepcji legło założenie, wedle którego naturalnie ludzkim sposobem wchodzenia w interakcje z soba, innymi i ze światem jest fabulacja (czyli tworzenie opowieści). Przy jej użyciu człowiek wykształcił: „złożony świat wewnętrzny, dzięki czemu zdołał zinternalizować świat zewnętrzny - by następnie eksternalizować go, dosłownie kształtując tym samym świat zewnętrzny wedle własnych wyobrażeń. To przełom, dzięki któremu - oto konstytutywna teza - pozostajac præédmiotem tożsamego z życiem ewolucyjnego eksperymentu, człowiek zdołał mentalnie go przekroczyć, stając się ponadto świadomym podmiotem eksperymentowania" (Żychliński 2014, 235).

Wyłania się stąd zadanie filologii, która może (autor wielokrotnie to podkreśla: może, niekoniecznie musi czy powinna) rozpoznać fikcje jako eksperymenty myślowe i zająć się ich „efektywnym wykładaniem z ewolucyjnego punktu widzenia” (Żychliński 2014, 243). Pojmowanie fikcji jako symulacji rzeczywistości, jako odpowiedzi na pytania o sens bycia człowiekiem, kieruje ku badaniu przekazów jako „egzystencjalnie istotnych eksperymentów myślowych” (Żychliński 2014, 243). I jest to według autora „bodaj jedyna szansa na uratowanie 
antropotechnicznego - czyli dotyczącego wiedzy (także autokreacyjnej) o tym, co znaczy być człowiekiem - potencjału fikcji, które znajdują się dziś w potężnym kryzysie" (Żychliński 2014, 245). (Na marginesie: skoro jest to jedyna szansa, to filologia raczej jednak musi $z$ niej skorzystać...)

Oryginalna, samodzielna, pożyteczna - nieczęsto zdarzają się takie książki. Zmuszają do odpowiedzi, pomagając w jej udzieleniu.

\section{Laboratorium ludzkiej osobności}

Uważam książkę Laboratorium antropofikecji za doniosłą i przełomowa - nie w tym sensie jednak, że ustanawia ona nowa praktykę badawczą, lecz w tym, że obnaża niedostatki paradygmatu humanistycznego dokładnie w tych miejscach, których autor broni. Książka pomaga również - niejako wbrew własnym tezom - zrozumieć, którędy nie dojdziemy do antropologii literatury. Ale krytyczne otrzeźwienie zawdzięczamy wyrazistości tez sformułowanych przez autora.

Będę więc polemizować z Żychlińskim. Czynię to jednak w nadziei na kolejne studia i rozprawy, w których autor rozwinie swoje myśli, a rozwieje moje wattpliwości. Aby nadziei dopomóc, wyostrzę swoje stanowisko. Tak uproszczone, składa się ono zaledwie z jednego choć złożonego - problemu. Mam mianowicie wrażenie, że laboratorium skonstruowane przez Żychlińskiego, choć fascynujące, jest zamknięte na trzy spusty. Pierwsze zamknięcie ma charakter antropologiczno-komunikacyjny, drugie - estetyczno-aksjologiczny, trzecie medialny. Zamknięcia te można wyrazić inaczej, pytając, kogo autor do laboratorium nie wpuści.

\section{Laboratorium nieistniejącego gatunku}

$\mathrm{Na}$ pytanie, kogo bramka zatrzyma, odpowiadam, po pierwsze, że będa to istoty nie dysponujące językiem ludzkim. Z punktu widzenia poznawczego wywód z pierwszej części książki przekazujący aktualny stan wiedzy na temat różnicy granicznej między człowiekiem i zwierzęciem jest perfekcyjny i przekonujący. Ogromna porcja wiedzy zawarta w tych rozważaniach jest nie do odrzucenia i nie do przecenienia. Akceptuję zatem - jako poparte odwołaniem do dziesiątków źródeł - rozliczne twierdzenia, że nawet szympansy, a więc zwierzęta najbardziej do ludzi zbliżone, nie dysponują językiem i złożonymi systemami intencjonalnymi. Akceptuję to, a zarazem odnoszę wrażenie, że dla laboratorium antropologicznego rozważania te kończą pewien eksperyment zamiast go zaczynać.

Dla uzasadnienia owej granicy równie dobrze można było powiedzieć: tylko ludzie hodują zwierzęta (nie znamy przypadku, by zwierzęta hodowały ludzi) i w związku tym do laboratorium pracującym nad autopojetycznością człowieka nie mają wstępu; albo: tylko ludzie 
przeprowadzają eksperymenty na zwierzętach, sprawdzając na przykład, czy zwierzęta dysponuja językiem i systemami intencjonalności, w związku z czym do laboratorium, w którym pracować się będzie nad wyższymi systemami intencjonalności, zwierzęta nie będą wpuszczane (bo po co); albo: tylko ludzie osiagnęli władzę pozwalająca nakazać zwierzętom, by żyły w określony sposób i umierały w określonym momencie... Nigdzie i nigdy nie spotkaliśmy się z sytuacją odwrotna. Zdumiewająca jest przecież łatwość, z jaką autor monografii poświęconej fikcjom lekceważy właśnie fikcje, w których poznajemy rzeczywistości odwrócone: oto Polifem konsumuje od czasu do czasu kanapkę z człowieka; Guliwer trafia do krainy Brobdingnag, w której olbrzymy moga zniewolić człowieka; w serii filmów Obcy poznajemy pozaziemską istotę, która potrzebuje ludzkiego ciała jako kokonu...

Fikcje te są istotne nie dlatego, że przynoszą obraz innego świata, lecz dlatego, że uświadamiają rozmiar pozajęzykowego oddzielenia człowieka od istot nie-ludzkich. Właśnie ów rozmiar sprawia, że na straży granicy stoją prawo, powszechna obyczajowość i nauka (medycyna, biologia, chemia organiczna, fizyka). Nie dostrzegam żadnego eksperymentu w udowadnianiu, że język ludzki przynależy jedynie ludziom. Prawdziwy eksperyment polegałby na wyjaśnieniu, jak doszło do tego, że na fundamencie językowym zbudowano imperium przemocy, które w kontekście różnicy językowej nie daje się ani zrozumieć, ani usprawiedliwić.

Język nie tłumaczy bowiem szerokiej i głębokiej przepaści wytwarzanej przez różnice statusu prawnego, kondycji, funkcji, kierunku zależności. Wynika z tego, że język, stanowiąc warunek graniczny człowieczeństwa, służy również jako podstawa praw, władzy, przemysłu, nauki... Laboratorium antropofikcji powinno być takim miejscem, gdzie owe granice i ich konsekwencje są rozgrywane i rozrywane, rozważane i podważane na dziesiątki sposobów nawet gdyby powodem było czysto poznawcze zainteresowanie kartografia egzystencji. Autor przekonuje nas, że antropologia fikcji zajmuje się człowiekiem, który wystawiając sobie bycie (jakimś) człowiekiem staje się (innym) człowiekiem. Otóż ta autarkiczna i autoteliczna gra doznaje ciekawego wstrzasu, gdy pod wpływem fikcji zaczynamy wystawiać sobie, jaki byłby człowiek, gdyby na zdolności mówienia nie zdołał zbudować potężnego gmachu władzy nad innymi gatunkami. (Albert Einstein powiedział, że gdyby szczur był o $20 \mathrm{~kg}$ cięższy, nie wiadomo, kto byłby panem ziemi...).

Jakie konsekwencje dla autokreacyjnych wysiłków człowieka niesie inne eksperymentowanie na definicji człowieka? W tekście Manifest gatunków stowarzyszonych (Haraway 2012) Donna Haraway pisze, że homo sapiens nigdy nie był sam. Zawsze towarzyszyły mu zwierzęta - zwłaszcza te od kilkudziesięciu tysięcy lat stopniowo udomawiane. Ich współistnienie prowadzić może (i powinno) do formułowania apeli o inne relacje. Istotne dla antropologii filologicznej byłoby jednak dostrzeżenie, że zwierzęta od zawsze dookreślały i współtworzyły tożsamości ludzkie. Mówiąc inaczej, poza-ludzkie od zawsze było (wypartym) 
elementem definicji tego, co ludzkie. Nawet bowiem jeśli człowiek sam siebie stwarzał poprzez język, snucie opowieści i eksperymentowanie - nigdy nie istniał sam. Jego język porządkował rzeczywistość, jego opowieści splatały część owej rzeczywistości, a część pętały lub unieważniały, wreszcie eksperymenty pozwalały mu odzyskiwać sprawczość w dziejach za cenę stłumienia sprawczości innych istot. Żychliński jako badacz antropofikcji stwierdza: „próby podejścia do starej kwestii [granicy człowiek - zwierzę] podejmowane pod szyldem posthumanistycznej kompensaty jawią się jako głęboko niejasne i zamglone" (Żychliński 2014, 59). Zdanie to, samo w sobie protekcjonalne i filozoficznie zamglone, przyjmuję do wiadomości jako stanowisko autora. I zarazem uważam, że właśnie w laboratorium antropofikcji niejasne i zamglone rzeczy ludzkie (granice i konsekwencje granic między człowiekiem i środowiskiem) powinny znajdować się $\mathrm{w}$ centrum uwagi. W przeciwnym wypadku laboratorium zajmowałoby się tylko tym, co rzęsiście oświetlone. A takim sprawom do czego potrzebny jest eksperyment?

\section{Laboratorium arcydzieł}

Przechodzę teraz do drugiego zamknięcia - estetyczno-aksjologicznego - ponawiając pytanie, kogo lub czego autor do laboratorium nie wpuści. Tym razem odpowiedź brzmi: kiepskiej fikcji.

W całej książce pojawiają się - wystarczająco często, abym miał prawo uznać to za trwały pogląd autorski - zdania o wyraźnie normatywnym wydźwięku (co stanowi kontynuację szkicu Inne tradycje. O barbaraynnstwie kiczu z książki Wielkie nadzieje i dalsz̧e rozważania) (Żychliński 2013). Są to niczym nie pogłębione, pozbawione uzasadnień arystokratyczne prychnięcia, formułowane z pozycji i przy użyciu stylistyki smakosza: „Niezależnie od medium to talent twórcy jest gwarantem poznawczej efektywności (wizja stanowi poręczenie wglądu). Słabe powieści, słabe wiersze, słabe filmy, słabe seriale czy słabe gry nie dlatego są kiepskie, że to powieści, wiersze, filmy, seriale czy gry, lecz dlatego, że ich twórca czy twórcy niewiele mieli do powiedzenia. Instynkt narracyjny sprawia, że jesteśmy głodni opowieści - ale gros historii konsumowanych na co dzień to oczywiście narracyjne fast foody” (Żychliński 2014, 34); „,...] dzisiejsza popularność najwybitniejszych seriali, cokolwiek sądzilibyśmy o ich jakości i znaczeniu, nie z jakości się bierze, lecz z przystępności samego medium” (Żychliński 2014, 261); „fabuły są jak cukier, konsumpcyjne nieumiarkowanie nam nie służy” (Żychliński 2014, 351); „Proza wydrążona z poezji to rozpasane fabularne fikcje jednorazowego użytku (smaczne niekiedy, podobnie jak słodycze i inne przekąski)" (Żychliński 2014, 361).

Rozumiemy zatem, że istnieją fikcje wartościowe i bezwartościowe (albo: niewiele warte). Gwarantem jakości tych pierwszych sa: talent, wizja, istotna treść (coś do powiedzenia), a wyznacznikiem tych drugich - schematyczność wytworzenia, łatwa przyswajalność, pozorna 
wartość odżywcza. Rozróżnienie to nie zostało osadzone w jakimś systemie aksjologicznym ani podparte argumentami. Odwołuje się ono do zdroworozsądkowych poglądów elity i służy obsadzeniu pozycji arbitra smaku, użyczającego miejsca obok siebie ludziom o podobnych gustach. Kto mówi, że coś jest „literackim fast foodem”, daje do zrozumienia, że smak nieomylnie pozwala mu odróżnić ,fast foody” od „slow foodów” i że eksplikacja podstaw jest tu zbędna.

Nie przeszkadza mi szczypta banału w oryginalnej książce. Nie przeszkadza dyscyplinujący charakter autorskich sądów (kto lubi literackie fast foody, powinien się zawstydzić). Przeszkadza mi tryb ustanowienia oczywistości i jej przedmiotowa treść, pozostawiające poza granicami laboratorium wszystkie problemy, które z samym podziałem na „wartościowe” i „kiepskie” się wiążą. Można by przecież sądzić, że właśnie laboratorium antropofikcji będzie odpowiednim miejscem do postawienia pytań zasadniczych: skąd się bierze i do czego służy samo rozróżnianie fikcji na dobre i niedobre? Być może jest ono jedną z antropofikcji - wartą rozważenia. Jeśli należy do aktywności narracyjnych, służy do rozplatania i zaplatania relacji ze światem. Jeśli tak, to autor przy użyciu owych dietetycznokulinarnych toposów usiłuje odwiązać się od jednej społeczności, a związać z inna, podczas gdy powinien przeprowadzić eksperyment nad samym tworzeniem więzi poprzez wartościowanie...

Tymczasem, odwołując się ponownie do fikcji stwarzających człowieka (i społeczeństwo), należałoby zapytać: czy możliwe jest pomyślenie istoty ludzkiej, która nie ocenia? Czy potrafilibyśmy porozumieć się z taką istotą? Czy człowiek wolny od oceniania nie byłby dla nas bogiem? Albo idiotą? Albo nadczłowiekiem? Intuicje z tym związane wyrażali bardzo liczni fikcjotwórcy: romantycy, zabraniający krytykom oceniać dzieła literackie (dzieło można tylko przeżyć); Nietzsche piszący o nadczłowieku jako istocie wolnej od resentymentu; Dostojewski przedstawiający „,pięknego człowieka”, który nikogo nie osądza, ponieważ wie, że kierowanie się w życiu samą prawdą może być niesprawiedliwe; postmoderniści proponujący „,nonjudgemental interpretation”... Autor mógłby odrzucić te sugestie, ponieważ odwołuja się one do propozycjonalnej zawartości literatury. Łatwo jednak znaleźć podstawę wspólną, pytając w zgodzie z zawartością książi: jak musiałby przebiegać proces ewolucyjny, aby powstał człowiek, który nie ocenia? I jak wyglądałoby społeczeństwo nie posługujące się dystynkcjami? Rozważenie tych kwestii pozwoliłoby osłabić owego ducha heglizmu, który spowija rozważania zawarte w Laboratorium antropofikciji, ducha polegającego na sumowaniu wiedzy ogólnoludzkiej dla uznania, że wartościowe jest tylko to, co już zwyciężyło w procesie ewolucyjnym.

Mogę jeszcze ściślej przyjąć założenia Arkadiusza Żychlińskiego i - chwilowo przejść na jego stronę. Wówczas okaże się, że banalne rozróżnienie na dobre i kiepskie fikcje, tak powszechne, iż oślepiające nawet uważnego badacza kultury, stanowi w kontekście rozważań autora problem centralny - prowadzi bowiem do pytania o antropologiczne 
funkcje oceniania fikcji. Autor pisze, że fikcje prowadzą ku eksperymentom antropologicznym (albo że fikcje są takimi eksperymentami). Być może jednak - o czym autor nie pisze - oceny są współczynnikiem owych eksperymentów. Trzeba więc dodać do rozważań zawartych w książce: skoro Żychliński wartościuje fikcje, to znaczy, że tworzenie fikcji jest wmontowane w dynamikę konkurencji i wspólnotowości. Poprzez fikcje ustanawiamy hierarchie i poprzez fikcje tworzymy więzi. Ludzkie przekraczanie własnego usytuowania w biologicznym, społecznym i historycznym bycie dokonuje się poprzez fikcje, które istnieją nie w próżni, lecz w społecznej komunikacji. A tworzenie fikcji (stwarzających człowieka) wiąże się z wartościowaniem, które również jest pewnego rodzaju fikcją (hierarchii, zmiany, postępu). Prawdziwy eksperyment nie polega na tym, by sprawdzić, czy możliwe jest oddzielenie dobrych opowieści od kiepskich - bo do takiego odgraniczenia wystarczy odrobina władzy (spoczywającej na przykład w naukowym dyskursie). Rzeczywisty eksperyment zaczyna się wtedy, gdy pytamy, dlaczego ludzie wartościują fikcje i jaką rolę w autoewolucji owo wartościowanie spełniło.

Autor zdaje się nas przekonywać, że koniec końców i tak wykluczymy to, co kiepskie, by poprzestać na tym, co wybitne. Pozwolę sobie jednak zapytać, cytując autora: „»Doprawdy?«” (Żychliński 2014, 128, fragment 48). Skoro „fikcja” w książce Arkadiusza Żychlińskiego to praktyka opowiadania i wytwarzania tożsamości ludzkiej, wobec tego kiepska fikcja odsyła nie tylko do literatury, lecz także do „kiepsko opowiedzianego życia” - nudnego, pozbawionego kreatywności i potencji autotransgresyjnych. Wnioskowanie powyższe skłaniałoby nas do wyrzucenia „rewolucji życia codziennego” Raoula Vaneigema, „wynajdywania codzienności” Michela de Certeau, „człowieka w teatrze życia codziennego” Ervinga Goffmana, „psychoteologii codzienności” Erica Santnera i kilkadziesięciu innych frapujących fikcji poświęconych rutynie życia codziennego. Te socjologiczne, etnograficzne i antropologiczne fikcje dotyczą trywialności mieszczańskich, najbardziej rekursyjnych, opartych na maksymalizacji powtórzeń i minimalizacji inwencji. W skład owych codzienności wchodzi konsumpcja tego, co banalne - kiepskich filmów, programów telewizyjnych, artykułów prasowych, dzieł literackich. Trzeba niezmierzonej cierpliwości, by poddać to obserwacji, a także autentycznej ciekawości, by powstrzymać się przed łatwą dyskwalifikacją. Wtedy życie jako kiepska fikcja staje się podstawą odkrywczej analizy, która wskazuje autokreacyjne - bardzo powolne - ewoluowanie. Można pójść krok dalej i wskazać na fast foodowy przebój roku 2012, czyli Piéćdziesiat twaray Greya E.L. James - poddany kapitalnej interpretacji przez Evę Ilouz w książce Hardkorowy romans (2015). Ilouz odsłania istotny aspekt emancypacyjny skryty w czytadle, polegający na wymyśleniu relacji sado-masochistycznej jako rozwiązania konfliktu wolności jednostkowej i więzi partnerskiej...

Uważam więc, że autor, posługując się zdawkowymi i żartobliwymi ocenami kiepskich fikcji uznał, że usytuował się na zewnątrz eksperymentu - że staną na twardej ziemi 
obiektywnych ocen. Wypreparował więc (po raz kolejny dychotomiczny) podział na fikcje dobre i kiepskie, nie zauważając, że razem z kiepskimi fikcjami wyrzuca trzy sprawy za drzwi laboratorium: 1) ocenianie jako prawdopodobny współczynnik rozwoju człowieka; 2) autokreacyjność skrytą w banalności codziennego (nudnego, mieszczańskiego) życia; 3) odczytanie kiepskich fikcji odnajdujące w nich autokreacyjną antropofikcję. Wydaje się, że pominięcie tych zagadnień wyniknęło z odrzucenia społecznego aspektu antropologii, czyli z pominięcia społeczeństwa jako współpracującej, żywej, dynamicznej sieci fikcji. Człowiek nigdy i nigdzie nie istnieje przecież sam: sam siebie nie rodzi, nie płodzi, nie uczłowiecza, nie uspołecznia. Jeśli wymyśla fikcje, to dzięki innym, wobec innych i dla innych, nawet jeśli robi to przeciwko nim. Ludzka autopoiesis nigdy nie jest „auto” - zawsze jest wytwarzaniem siebie we współpracy, w kontakcie, w opozycji i w konflikcie z innymi. Zawierzenie podziałowi na fikcje „wartościowe” i „bezwartościowe” odsłoniło problem, który autor chciał umiejscowić poza laboratorium, by zyskać w ten sposób warunki do niezakłóconego i czystego eksperymentu. Ale tak prowadzony eksperyment dobiega końca, zanim na dobre się zaczyna.

\section{Laboratorium pozamedialnej fikcji}

I wreszcie zamek trzeci - medialny. Tym razem za drzwiami laboratorium zostaje, umownie rzecz ujmując, Marshall McLuhan. A w szerszym rozumieniu: antropolog mediów.

Wykluczenie to ma charakter paradoksalny, ponieważ wynika z bardzo szerokiego ujęcia mediów. Sądzić można, że autor chciał zapobiec ograniczeniu refleksji do samej literatury, w związku z czym dokonał maksymalnej ekstensji pojęcia „fikcja”, by mogło ono objać dzieła filmowe, komputerowe czy teatralne. Przykładowo komentując zdanie Briana Boyda „ewolucja pozwala nam lepiej zrozumieć sztukę i literaturę” (Żychliński 2014, 15), autor stwierdza: „Wszędzie tam, gdzie Boyd mówi o sztuce i literaturze, ja proponuję mówić o fikcjach” (Żychliński 2014, 15). W innym miejscu pisze, że fikcje są uniwersalne „niezależnie od medium, w którym się materializują” (Żychliński 2014, 30), do czego dodaje stwierdzenie (niekoniecznie przekonujące), że wszystkie media fikcji łączy „poszukiwanie najsprawniejszej formuły narracji” (Żychliński 2014, 31). Rozumie zaś przez fikcję „sztukę ewokowania rzeczywistości niezależnie od medium” (Żychliński 2014, 17); pełniej: „Fikcja to, mówiąc najogólniej, zinstytucjonalizowana narracja (czy szerzej nawet: wypowiedź artystyczna), czyli opowieść umieszczona w pewnej instytucjonalnej ramie: może to być na przykład literatura, film czy teatr [...]. Fikcja to, jak akcentuje to zwłaszcza język polski, opowieść wymyślona i stąd nieprawdziwa w faktualno-referencyjnym sensie, a jednak, jeśli jest udana, [staje się] prawdziwa w sensie prawdy, która, co symptomatyczne, nie ma właściwie własnej nazwy [...], a którą moglibyśmy określić mianem prawdy egzystencjalnej (czyli pewnego wglądu w uniwersalnoludzki życio-rys)" (Żychliński 2014, 18). 
Stwierdzenia powyższe są podobne do założeń (po większej części później zarzuconych) $\mathrm{z}$ lat sześćdziesiątych i siedemdziesiątych $\mathrm{XX}$ wieku, czynionych przez narratologów (Propp, Greimas), którzy wychodzili z założenia, że narracje są przenośne: skoro narracja jest kombinacją funkcji i wartości określających pewien przebieg zdarzeń, wobec tego funkcje można przenieść z literatury do filmu bez utraty wartości istotnych dla przekazu. Jednakże niemal w tym samym czasie w humanistyce pojawiła się szkoła dokładnie przeciwna. $\mathrm{Na}$ początku lat sześćdziesiątych XX wieku - między innymi pod wpływem refleksji kanadyjskiego historyka ekonomii Harolda A. Innisa poświęconej związkom między środkami komunikacji i rozwojem cywilizacji (Empire and Communications; The Bias of Communication) (1950; 1951) - powstał nowy paradygmat badawczy. Założycielskie znaczenie dla nowego podejścia miała seria - częściowo tylko ze sobą powiązanych - studiów: Marshalla McLuhana The Gutenberg Galaxy. The Making of Typographic man (1962); Claude Lévi-Straussa Myśl nieoswojona (2001); Erica Havelocka Predmowa do Platona (2007); Jacka Goody'ego i Iana Watta The Consequences of Literacy (1963); Waltera Onga The Presence of the Word: Some Prolegomena for Cultural and Religious History (1967). W tym podejściu - które można nazwać ontologia komunikacji kluczowe media poszczególnych etapów cywilizacji, takie jak oralność, piśmienność czy (początkująca) elektroniczność zostały opisane jako typy komunikacji decydujące o antropologicznym wyposażeniu człowieka i całokształcie życia społecznego. Fundamentem nowego paradygmatu stało się założenie, że wszystkie aspekty społecznego uniwersum są korelatami środków porozumienia. W ujęciu takim instytucje życia zbiorowego (władza, prawo, obyczaj, religia, sztuka), więzi społeczne, sposoby komunikacji codziennej i uroczystej, techniki pamięci i transmisji tradycji, a także umysł ludzki są wytworami dominującego medium i jednocześnie aktywnościami wywierającymi na owo medium stały - choć nie do końca wyjaśnialny - wpływ. Zgodnie z tym zmiana medium (np. przejście od mowy do pisma i od pisma do elektroniki) pociąga za sobą zmianę umysłu i przekształcenie wszystkich parametrów życia społecznego.

Chciałbym bardzo wyraźnie podkreślić, że ontologia komunikacji nie wyznawała zasady determinizmu medialnego. Ong uważał, że pismo zmieniło „umysłowość człowieka”, Goody badał wpływ pisma na konstrukcję państwa, McLuhan przekonywał o przemianach percepcji następujących pod wpływem radia i telewizji, ale wszyscy posługiwali się nie tyle logiką jednokierunkowej determinacji, co logiką sprzężenia zwrotnego: człowiek zmienia medium, które zmienia człowieka, który stwarza nowe medium, które... Jednak zmiana raz wprowadzona jest już nieodwracalna: człowiek piśmienny nie może cofnąć się do etapu człowieka oralnego, ponieważ jego sposób myślenia jest już inny.

Arkadiusz Żychliński sądzi podobnie, na przykład wtedy, gdy uznaje wynalazek książki za równy pod względem doniosłości kołu (Żychliński 2014, 31). Albo gdy pisze: „[...] moment powstania powieści jako nowego gatunku narracyjnego oznacza narodziny potężnego 
antropologicznego laboratorium, które umożliwi eksperymentalną eksplorację ludzkiej samowiedzy na niespotykaną dotąd skalę" (Żychliński 2014, 26). Atrybucja epitetów (potężny, niespotykany) i związany z tym patos zakrywaja tu pewną kłopotliwą niekonsekwencję. Wcześniej autor przekonywał, że medium jest nieistotne, teraz pisze, że medium współtworzy człowieka. Raz więc pisze, że liczy się fikcja, bo to ona poszerza możliwości samowiedzy, a chwilę później - że sprawczą rolę odgrywa medium. Tu ujawnia się wspomniany przeze mnie paradoksalny charakter wykluczenia: właśnie dlatego, że autor zamazał różnicę między fikcją i medium, nie mógł uwzględnić antropologicznego działania mediów, choć równocześnie sam takie działanie zakłada. W rezultacie przedstawia ekstatyczną historię umysłu, który poszerza swoje granice, czerpiąc z wszelkich fikcji (niezależnie od ich medialnej materializacji) podnietę dla samowiedzy i zarazem zawdzięczając swój rozwój potędze wynalezionego medium.

Medium nie da się więc wystawić poza drzwi laboratorium. Kiedy poddamy je badaniu, będziemy musieli przyjąć hipotezę, że: pismo zmieniło umysł (Ong, Goody, McLuhan), malarstwo i fotografia zmieniły nasz zmysł wzroku (Benjamin, Warburg), film zmienił reguły kojarzenia (McLuhan)... Nie chodzi już o oddziaływanie arcydzieł (literatury, malarstwa czy filmu), o fikcję zadaną umysłowi ludzkiemu przez wybitne dzieła, lecz właśnie o najbardziej rutynową z rutyn - o medialne środowisko ludzkie, w którym przebywamy jak w niewidzialnym laboratorium. Codziennie i niemal automatycznie człowiek korzysta z mediów, które przekształcaja jego świadomość i jego sensorium.

Medium nie jest zatem antropologicznie neutralne, ponieważ każde z nich aktywizuje inną kombinację zmysłów i umysłu, wytwarzając innego człowieka. Można wyobrazić sobie, jak do tytułowego laboratorium antropofikcji wkracza na różnych etapach rozwoju różny człowiek, który jest wytwórca i wytworem mediów. Człowiek ten jest sprawca antropologicznych zmian wywołanych przez media, które skonstruował. Sam nie mógłby siebie zmienić, więc za każdym razem gdy wymyśla nowy środek, wpada w pułapkę, którą stworzył, aby z pułapki się wydostać.

Bez założenia, że medium bierze udział w sprawczej historii człowieka, nie ma eksperymentu.

\section{Otwieranie laboratorium}

Laboratorium antropofikcji jest świadectwem niebywałej erudycji i znakomitego opanowania lektur. I jest fascynująca propozycja odnowienia filologii. Ale propozycja złudną. Anachroniczną i potwierdzająca, że do laboratorium autor wpuścił trzech starych graczy język, arcydzieła i czystą opowieść.

Aby otworzyć to laboratorium, trzeba przyjąć, że człowiek nie istnieje osobno (więc nie można zdefiniować go wyłącznie w oparciu o to, co ludzkie), że potrafi czerpać impulsy 
antropologicznych zmian nie tylko z arcydzieł (więc nie wolno nam pomijać kiepskich fikcji) i nie jest wyłącznym sprawcą antropomodyfikacji (więc nie można pominąć antropokreacyjnej roli mediów). W jednym przecież zgadzam się z autorem: nowa fikcja antropologiczna jest coraz bardziej potrzebna - człowiekowi, literaturze, życiu. 


\section{Wykaz literatury}

Goody, Jack, i Ian Watt. 1963. "The Consequences of Literacy”. Comparative Studies in Society and History, 3 (5).

Haraway, Donna. 2012. „Manifest gatunków stowarzyszonych”. Tłum. Joanna Bednarek. W Teorie wywrotowe. Antologia przekładów, red. Agnieszka Gajewska. Poznań: Wydawnictwo Poznańskie.

Havelock, Eric. 2007. Przedmowa do Platona. Tłum. Paweł Majewski. Warszawa: Wydawnictwa Uniwersytetu Warszawskiego.

Illouz, Eva. 2015. Hardkorowy romans. Tłum. Jacek Konieczny. Warszawa: Wydawnictwo Naukowe PWN.

Innis, Harold. 1950. Empire and Communications. Toronto: University of Toronto Press.

Innis, Harold. 1951. The Bias of Communication. Toronto: University of Toronto Press.

Lévi-Straussa, Claude. 2001. Myśl nieoswojona. Tłum. Andrzej Zajączkowski. Warszawa: Wydawnictwo KR.

McLuhan, Marshall. 1962. The Gutenberg Galaxy. The Making of Typographic Man. Toronto: University of Toronto Press.

Ong, Walter. 1967. The Presence of the Word: Some Prolengomena for Cultural and Religious History. Yale: Yale University Press.

Żychliński, Arkadiusz. 2013. Wielkie nadrieje i dalsz̧e roz̧ważania. Poznań: Wydawnictwo Nauka i Innowacje.

Żychliński, Arkadiusz. 2014. Laboratorium antropofikcji. Dociekania filologicz̨ne. Poznań-Warszawa: Wydawnictwo UAM. 
Przemysław Czapliński - Polski krytyk literacki, profesor zwyczajny literatury współczesnej. Pracuje w Instytucie Filologii Polskiej Uniwersytetu im. Adama Mickiewicza. Zasadniczym przedmiotem jego zainteresowań jest konfrontacja literatury z nowoczesnością i wynikające stąd problemy: konflikt modernizacji i tradycji, przemoc nowoczesna (wojna, obozy, Zagłada) jako narzędzie przebudowy człowieka i społeczeństwa, zanik i powrót utopii jako rezultaty kryzysu projektowania przyszłości. Autor m.in Powrót centrali: literatura w nowej rz̧ecsywistości (2007), Polska do wymiany. Późna nowoczesność i nasze wielkie narracje (2009), Resz̨tki nowoczesności (2011).

\section{DANE ADRESOWE:}

Instytut Filologii Polskiej UAM

ul. Fredry 10

61-701 Poznań

EMAIL: czaple@amu.edu.pl

CYTOWANIE: Czapliński, Przemysław. 2015. „Zamykanie laboratorium.” Praktyka Teoretyczna 2(16): 242-254.

DOI: $10.14746 /$ prt.2015.2.13

AUTHOR: Przemysław Czapliński

TITLE: Enclosing the laboratory

ABSTRACT: Review essay of Arkadiusz Żychliński's book Laboratorium antropofikcji. Dociekania filologične (2014).

KEYWORDS: litrerary criticism, philology, posthumanities, media studies 